\title{
Serum electrolytes and outcome in patients undergoing endoscopic gastrostomy
}

\author{
Joana VIEIRA ${ }^{1}$, Gonçalo NUNES ${ }^{1}$, Carla Adriana SANTOS $^{1}$ and Jorge FONSECA ${ }^{1,2}$
}

Received 8/7/2017

Accepted 19/10/2017

\begin{abstract}
Background - Percutaneous endoscopic gastrostomy (PEG) is a gold standard for long term enteral feeding. Neurologic dysphagia and head/neck cancer are the most common indications for PEG as they can lead to protein-energy malnutrition and serum electrolyte abnormalities, with potential negative impact on metabolic balance. Refeeding syndrome may also be related with severe electrolyte changes in PEG-fed patients and contribute to poor prognosis. Objective - This study aims to evaluate the changes in serum concentrations of the main electrolytes and its possible association with the outcome. Methods - Retrospective study of patients followed in our Artificial Nutrition Clinic, submitted to PEG from 2010 to 2016, having head/neck cancer or neurologic dysphagia, who died under PEG feeding. Serum electrolytes (sodium, potassium, chlorine, magnesium, calcium and phosphorus) were evaluated immediately before the gastrostomy procedure. Survival after PEG until death was recorded in months. Results - We evaluated 101 patients, 59 with electrolyte alterations at the moment of the gastrostomy. Sodium was altered in 32 (31.7\%), magnesium in $21(20.8 \%)$, chlorine in $21(20.8 \%)$, potassium in $14(13.8 \%)$, calcium in $11(10.9 \%)$ and phosphorus in $11(10.9 \%)$. The survival of patients with low sodium ( $<135 \mathrm{mmol} / \mathrm{L})$ was significantly lower when compared to patients with normal/high values, 2.76 months vs 7.80 months, respectively $(P=0.007)$. Conclusion - Changes in serum electrolytes of patients undergoing PEG were very common. More than half showed at least one abnormality, at the time of the procedure. The most frequent was hyponatremia, which was associated with significantly shorter survival, probably reflecting severe systemic metabolic distress.
\end{abstract}

HEADINGS - Enteral nutrition. Gastrostomy. Electrolytes. Hyponatremia.

\section{INTRODUCTION}

Percutaneous endoscopic gastrostomy (PEG) is the gold standard for long-term enteral feeding, longer than 3-4 weeks ${ }^{(1)}$. The main indication for PEG is dysphagia, which may be neurologic or a consequence of an obstructive disease. Regardless of the cause, dysphagia reduces food intake due to decreased swallowing efficacy, resulting in nutrient depletion ${ }^{(2)}$. When oral intake is not sufficient to meet the nutritional needs or the patient is unable to eat and/or drink safely (especially for pulmonary aspiration risk) and the gastrointestinal tract is functional, PEG allows an access for nutrition ${ }^{(3,4)}$. When patients with long-term dysphagia, due to neurologic disease or head and neck cancer, are referred for gastrostomy, they often present reduced food intake since weeks prior to the procedure ${ }^{(5,6)}$.

Electrolytes are substances that dissociate into negative or positively charged ions (anions and cations) when dissolved in water. They are widely distributed in body fluids, maintain physiological functions such osmotic balance, acid-base balance and intra and extracellular gradients, and play a key role in maintaining metabolic functions. The main extracellular electrolytes are sodium, chlorine and calcium. Potassium, magnesium and phosphate are the major intracellular electrolytes. Changes in their concentrations may affect multiple body functions ${ }^{(7,8)}$.
The refeeding syndrome is characterized by electrolyte disturbance (especially hypophosphatemia, hypomagnesemia and hypokalemia), clinical symptoms (peripheral edema or acute circulatory fluid overload) and disturbance in organ function (respiratory and cardiac failure or pulmonary edema). It occurs within the first 72 hours after starting nutritional therapy and the main strategies for its prevention include intensive electrolyte replacing therapy and thiamin infusion before starting refeeding with hypocaloric nutrition ${ }^{(9)}$. Gastrostomy patients are a risk group for this condition because they often present several of the risk factors for developing this syndrome, such as low body mass index (BMI), unintentional weight loss, starvation and low initial electrolyte concentration. Teams taking care of PEG patients should consider this risk and systematically monitors the serum electrolytes. After starting nutritional support in these patients, previously unable to sufficient feed, there is a sudden increase in glucose and insulin secretion, which causes changes in electrolytes, with increased sodium and water retention, and expansion of the extracellular volume. The main consequences are risk of heart failure and peripheral edema, redistribution of phosphate, potassium and magnesium with severe complications such as spasms or arrhythmias. In addition, phosphorus plays a key role in energy metabolism as part of the ATP structure and phosphorylation and dephosphorylation reactions ${ }^{(10)}$. Hypophosphatemia affects the production of ATP causing muscle

Departamento de Gastroenterologia, GENE - Artificial Feeding Team, Hospital Garcia de Orta, Almada, Portugal; ${ }^{2}$ CiiEM, Centro de Investigação Interdisciplinar Egas Moniz, Monte da Caparica, Portugal.

Correspondence: Gonçalo Nunes. Departamento de Gastroenterologia. Hospital Garcia de Orta. Av. Torrado da Silva, 2805-267. Almada, Portugal. E-mail: goncalo.n@hotmail.com 
weakness, rhabdomyolysis and impairment of hematopoiesis with symptoms of anemia and reduced oxygen delivering ${ }^{(9)}$. Other electrolyte change is hypokalemia, caused by insulin that leads to the movement of potassium into the cells, where it becomes trapped ${ }^{(11)}$.

Previous studies have already identified several risk factors for adverse effects after PEG placement as advanced age, male gender, low BMI, elevated C-reactive protein and low serum albumin ${ }^{(12-15)}$. Our team created two predictive survival models for PEG patients: one to predict early mortality, sooner than 3 weeks after the gastrostomy procedure ${ }^{(16)}$, other with a special focus in head or neck cancer PEG patients ${ }^{(6)}$. Nevertheless, these are complex predictive models. Reviewing the literature, we found only one study that classified an electrolyte abnormality, in that case severe hypernatremia, as an indicator of mortality in gastrostomized patients ${ }^{(17)}$

The aim of the present study was to evaluate the changes in serum electrolyte concentrations when patients underwent endoscopic gastrostomy and the possible associations between altered electrolyte serum levels and the clinical outcome.

\section{METHODS}

A retrospective analysis of a prospectively collected database was performed in patients followed in our Artificial Feeding Clinic at the Hospital Garcia de Orta, proposed and submitted to PEG from 2010 to 2016, and that died using PEG.

The following data was collected for each patient: age, gender, clinical indication for PEG, BMI, serum levels of the ions under study (sodium, potassium, chlorine, magnesium, calcium and phosphorus) and dates of gastrostomy and death. Survival was recorded in months after PEG until death. All the necessary data for the study were obtained using the clinical files of the Artificial Feeding Team (GENE) of our hospital. Patients who did not present all the data necessary for the study were excluded.

All patients or their legal representatives have signed the informed consent for the endoscopy and the gastrostomy. This study was conducted in accordance with the principles of the Helsinki declaration.

Patients underwent PEG after a 12-hour fast. Antithrombotic therapy was managed according to the most recent guidelines ${ }^{(18)}$. Defects in coagulation were corrected prior to the procedure. None of the patients received intravenous intensive fluid therapy in the $48 \mathrm{~h}-72 \mathrm{~h}$ before the procedure. Before endoscopic gastrostomy patients must be stable. Unstable patients were refused or postponed.

Two gastroenterologists performed all procedures and all the patients were under sedation. During the procedure, oxygen saturation, heart rate and electrocardiographic signs were monitored. The "pull" method was selected to perform the procedure in most cases. The "push" method was used for head and neck cancers ${ }^{(19)}$. Our team started using "push" method after a case of ostomy metastasis ${ }^{(20)}$. When using the "push" method there is no passage of the tube through the mouth, pharynx and esophagus allowing a safe procedure, without risk of seeding cancer cells in the gastrostomy tract.

Body mass index was obtained in most patients using the equation weight $/$ height $^{2}$. If patients were unable to easily stand up for weight and height evaluation, BMI was estimated using the Mid Upper Arm Circumference (MUAC), and regression equations described by Powell-Tuck and Hennessy ${ }^{(21)}$, which were previously been used and proved to provide a reliable BMI estimation in PEG feeding patients ${ }^{(22,23)}$. Each patient was classified according to age: having low weight if $\mathrm{BMI}<18.5 \mathrm{~kg} / \mathrm{m}^{2}$ for patients under 65 years or BMI $<22 \mathrm{~kg} / \mathrm{m}^{2}$ for patients 65 years old or older ${ }^{(24)}$.

A blood sample was obtained just before the endoscopic gastrostomy procedure, and serum electrolytes were measured as part of the global nutritional evaluation of patients. Normal cutoff values were considered, according institutional protocol of our hospital laboratory:

- Sodium: 135 - $145 \mathrm{mmol} / \mathrm{L}$;

- Chlorine: 95 - $108 \mathrm{mmol} / \mathrm{L}$;

- Calcium: $8.1-10.2 \mathrm{mg} / \mathrm{dL}$;

- Potassium: $3.5-5.0 \mathrm{mmol} / \mathrm{L}$;

- Magnesium: $1.5-2.1 \mathrm{mg} / \mathrm{dL}$;

- Phosphorus: $2.5-4.8 \mathrm{mg} / \mathrm{dL}$.

Statistical analysis was performed using the Statistical Package for Social Sciences (SPSS ${ }^{\circledR}$ Inc., Chicago, IL). Continuous variables are expressed as mean \pm standard deviation. Categorical variables are expressed as percentage. Nonparametric Spearman's correlation test and Mann-Whitney test were applied to compare variables without normal distribution and the parametric Student $t$-test where variables followed a normal distribution. Chi-square test was also used to compare nominal variables. All tests were performed at a $5 \%$ level of statistical significance.

\section{RESULTS}

We evaluated 101 patients (68 men; 33 women) aged between 36-100 years (mean: 68.7 \pm 15.14 years). The main characteristics of the population are described in TABLE 1 . The clinical indications for PEG were neurologic $(60.4 \%)$, including dementia, stroke, among others, and cancer $(39.6 \%)$, specifically head and neck cancer. Fifty-seven $(56 \%)$ patients presented low BMI.

TABLE 1. Baseline characteristics of the study population

\begin{tabular}{lc}
\hline Characteristic & Patients $(\mathbf{n}=101)$ \\
\hline Demographic & $68(67.3 \%)$ \\
Gender (male) & $68.7 \pm 15.14$ \\
Age mean (years) & $20.4 \pm 3.71$ \\
Body mass index & \\
Indication for PEG & $61(60.4 \%)$ \\
Neurologic $(\%)$ & $40(39.6 \%)$ \\
Cancer $(\%)$ & $\mathrm{Mean} \pm \mathrm{SD}$ \\
Electrolytes & $137.84 \pm 5.62$ \\
Sodium $\left(\mathrm{Na}^{+}\right)$ & $98.76 \pm 5.63$ \\
Chlorine $\left(\mathrm{Cl}^{-}\right)$ & $8.88 \pm 0.66$ \\
Calcium $\left(\mathrm{Ca}^{2+}\right)$ & $4.30 \pm 0.56$ \\
Potassium $\left(\mathrm{K}^{+}\right)$ & $2.17 \pm 2.93$ \\
Magnesium $\left(\mathrm{Mg}^{2+}\right)$ & $3.56 \pm 3.05$ \\
Phosphorus $\left(\mathrm{Pi}^{2}\right)$ & \\
\hline
\end{tabular}

At the moment of endoscopic gastrostomy procedure, $59(58 \%)$ patients had at least one electrolyte abnormality (FIGURE 1). Mean values of each electrolyte are shown in TABLE 1 . Sodium was altered in $32(31.7 \%)$ patients, magnesium in $21(20.8 \%)$, chlorine in $21(20.8 \%)$, potassium in $14(13.8 \%)$, calcium in $11(10.9 \%)$ and phosphorus in $11(10.9 \%)$ - TABLE 2 . For all the electrolytes, 


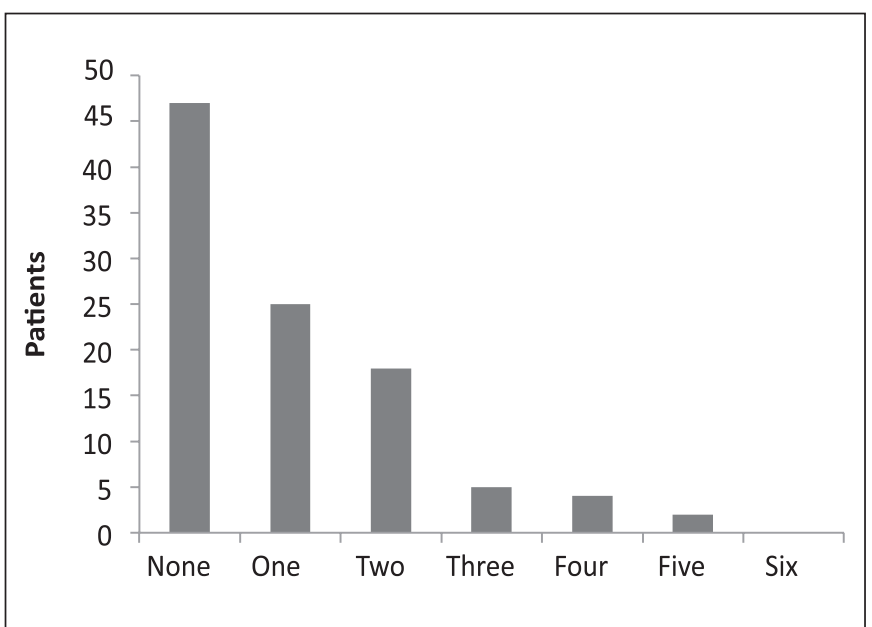

FIGURE 1. Patients per number of serum electrolyte abnormalities.

TABLE 2. Classification of electrolyte status according with serum values

\begin{tabular}{|c|c|c|c|}
\hline \multicolumn{4}{|c|}{ Total Patients $(n=101)$} \\
\hline Electrolytes & Low & Normal & High \\
\hline Sodium $\left(\mathrm{Na}^{+}\right)$ & $26(25.7 \%)$ & $69(68.4 \%)$ & $6(5.9 \%)$ \\
\hline Chlorine $\left(\mathrm{Cl}^{-}\right)$ & $19(18.8 \%)$ & $80(79.3 \%)$ & $2(1.9 \%)$ \\
\hline Calcium $\left(\mathrm{Ca}^{2+}\right)$ & $8(7.9 \%)$ & $90(89.2 \%)$ & $3(2.9 \%)$ \\
\hline Potassium $\left(\mathrm{K}^{+}\right)$ & $5(4.9 \%)$ & $87(86.2 \%)$ & $9(8.9 \%)$ \\
\hline Magnesium $\left(\mathrm{Mg}^{2+}\right)$ & $10(9.9 \%)$ & $80(79.3 \%)$ & $11(10.8 \%)$ \\
\hline Phosphorus (Pi) & $10(9.9 \%)$ & $90(89.2 \%)$ & $1(0.9 \%)$ \\
\hline \multicolumn{4}{|c|}{ Neurological Patients $(n=61)$} \\
\hline Electrolytes & Low & Normal & High \\
\hline Sodium $\left(\mathrm{Na}^{+}\right)$ & $14(22.9 \%)$ & $44(72.2 \%)$ & $3(4.9 \%)$ \\
\hline Chlorine $\left(\mathrm{Cl}^{-}\right)$ & $9(14.7 \%)$ & $51(83.7 \%)$ & $1(1.6 \%)$ \\
\hline Calcium $\left(\mathrm{Ca}^{2+}\right)$ & $4(6.5 \%)$ & $57(93.5 \%)$ & $0(0 \%)$ \\
\hline Potassium $\left(\mathrm{K}^{+}\right)$ & $3(4.9 \%)$ & $51(83.7 \%)$ & $7(11.4 \%)$ \\
\hline Magnesium $\left(\mathrm{Mg}^{2+}\right)$ & $4(6.5 \%)$ & $49(80.4 \%)$ & $8(13.1 \%)$ \\
\hline Phosphorus (Pi) & $6(9.8 \%)$ & $54(88.6 \%)$ & $1(1.6 \%)$ \\
\hline \multicolumn{4}{|c|}{ Cancer Patients $(n=40)$} \\
\hline Electrolytes & Low & Normal & High \\
\hline Sodium $\left(\mathrm{Na}^{+}\right)$ & $12(30 \%)$ & $25(62.5 \%)$ & $3(7.5 \%)$ \\
\hline Chlorine $\left(\mathrm{Cl}^{-}\right)$ & $10(25 \%)$ & $29(72.5 \%)$ & $1(2.5 \%)$ \\
\hline Calcium $\left(\mathrm{Ca}^{2+}\right)$ & $4(10 \%)$ & $33(82.5 \%)$ & $3(7.5 \%)$ \\
\hline Potassium $\left(\mathrm{K}^{+}\right)$ & $2(5 \%)$ & $36(90 \%)$ & $2(5 \%)$ \\
\hline Magnesium $\left(\mathrm{Mg}^{2+}\right)$ & $6(15 \%)$ & $31(77.5 \%)$ & $3(7.5 \%)$ \\
\hline Phosphorus (Pi) & $4(10 \%)$ & $36(90 \%)$ & $0(0 \%)$ \\
\hline
\end{tabular}

except potassium, deficiency was the most common alteration. Thirty-two (31.7\%) out of 101 patients died within the first month after PEG placement. Nineteen (18.8\%) patients died during the first three months after the procedure. There were no records of clinical features directly attributable to electrolyte changes.
Patient survival with low sodium $(<135 \mathrm{mmol} / \mathrm{L})$ was inferior compared to patients with normal/high sodium concentration (FIGURE 2). This major difference, 2.76 months' vs 7.80 months, was statistically significant $(P=0.007)$. No other electrolyte abnormalities were associated with patient survival. The difference in the two groups (low sodium and normal/high sodium) was not significant when considering age, gender, indication for PEG, BMI and other electrolyte serum concentration, with exception of chlorine that usually goes along with sodium movements (TABLE 3).

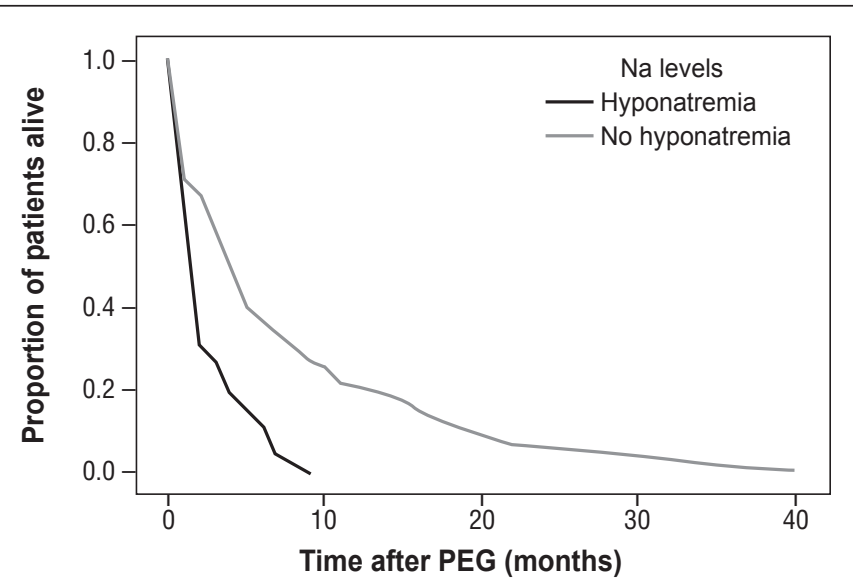

FIGURE 2. Kaplan-Meier survival analysis according to serum sodium level.

TABLE 3. Difference between groups according with serum $\mathrm{Na}$ concentration

\begin{tabular}{lccc}
\hline Variable & $\begin{array}{c}\text { Hyponatremia } \\
(\mathrm{Na}<135)\end{array}$ & $\begin{array}{c}\text { Normal or high } \\
\text { sodium }(\mathrm{Na} \geq 135)\end{array}$ & $\boldsymbol{P}$-value \\
\hline Age & $73.3 \pm 12.6$ & $67.8 \pm 15.8$ & 0.31 \\
Gender & $\begin{array}{c}\text { Male: } 19 \\
\text { Female: } 6\end{array}$ & $\begin{array}{c}\text { Male: } 49 \\
\text { Female: } 27\end{array}$ & 0.28 \\
Indication for PEG & $\begin{array}{c}\text { Neurologic: } 12 \\
\text { Cancer: } 11\end{array}$ & $\begin{array}{c}\text { Neurologic: } 47 \\
\text { Cancer: } 40\end{array}$ & 0.60 \\
Survival after PEG & $2.86 \pm 2.29$ & $7.80 \pm 9.15$ & 0.007 \\
Body mass index & $20.9 \pm 3.83$ & $20.2 \pm 3.67$ & 0.41 \\
Chlorine $\left(\mathrm{Cl}^{-}\right)$ & $92 \pm 4.38$ & $100 \pm 4.31$ & 0.001 \\
Calcium $\left(\mathrm{Ca}^{2+}\right)$ & $8.8 \pm 0.79$ & $8.9 \pm 0.61$ & 0.54 \\
Potassium $\left(\mathrm{K}^{+}\right)$ & $4.4 \pm 0.65$ & $4.3 \pm 0.52$ & 0.016 \\
Magnesium $\left(\mathrm{Mg}^{2+}\right)$ & $2.4 \pm 3.06$ & $2.1 \pm 1.4$ & 0.53 \\
Phosphorus $(\mathrm{Pi})$ & $3.3 \pm 0.8$ & $3.6 \pm 3.48$ & 0.63 \\
\hline
\end{tabular}

No statistically significant differences were found between gender in survival or in abnormal concentrations of serum electrolytes. Considering the two groups of diseases underlying dysphagia (head/neck cancer and neurologic disease), we did not find statistically significant differences in survival or any differences in abnormal concentrations of serum electrolytes. In particular, we did not find statistically significant differences in survival relative to the frequency of the low $\mathrm{Na}$ concentration when compared to the groups with head/neck cancer and neurologic disease. 


\section{DISCUSSION}

For the main enteral and parenteral nutrition societies, PEG is the preferred enteral feeding method in cases when nutritional support is required for longer than 3-4 weeks. This type of support leads to improvement in nutritional status, quality of life and overall survival ${ }^{(1,25)}$. Predicting mortality is important since gastrostomy should be avoided in patients with a few weeks' survival ${ }^{(16,26)}$. In the present study, regarding gender, men and women show a similar survival period after gastrostomy. Also, the outcome was similar regarding the two major groups of underlying diseases, head or neck cancer and neurologic disorders. In fact, hyponatremia was the only change with statistically significant decrease in survival. This condition is a very frequent electrolyte abnormality and, in hospitalized patients, may have prevalence as high as $30 \%{ }^{(27)}$. It is defined as a serum sodium concentration below $135 \mathrm{mmol} / \mathrm{L}$ and indicates body water excess or loss of water and sodium. The elderly patients present an increased prevalence of hyponatremia, which increases the risk of falls, fractures and cognitive deterioration ${ }^{(28)}$. In cancer patients, hyponatremia is also common, caused by the tumor or by the treatments. In these patients, hyponatremia is a poor prognostic factor even after confounding factors corrections ${ }^{(29)}$. Specially, head or neck cancer may occasionally be associated with development of inappropriate antidiuretic hormone secretion syndrome (SIADH), which is a cause of hyponatremia ${ }^{(30)}$. Nevertheless, this is not a suitable justification for the low sodium patients found in the present study, as hyponatremia was present in a large number (26 patients, $25.7 \%$ ) and equally divided between head or neck cancer and neurologic patients. Also, head or neck cancer patients are mostly men and regarding gender, men and women show a similar survival period after gastrostomy, in the present study.

Hyponatremia is considered a severity illness indicator, with mean serum sodium concentration being 5-6 mmol/L lower in hospitalized patients compared to healthy outpatients ${ }^{(31)}$. In the present study, hyponatremia patients present a significantly shorter survival. Hyponatremia of PEG patients may be looked as a surrogate marker of severe metabolic distress, resulting in poor outcome, although the presence of comorbidities may difficult any estimation of the risk attributable to hyponatremia alone ${ }^{(32)}$. Interestingly, the results our study differ from those found by Muratori ${ }^{(17)}$, who identified hypernatremia as an independent predictor of mortality after gastrostomy. This study took place at a tertiary center in Italy between March 1999 and December 2013 and 438 patients were included to evaluate the risk factors for early and delayed mortality after PEG placement. No other previous studies have assessed the impact of serum sodium levels in patients undergoing PEG for long-term enteral nutrition. From the clinical point of view, these major variations of serum sodium may be regarded as markers of severely disturbed homeostasis and poor outcome.

This study presents some limitations. It is a retrospective study carried out in a single hospital and consequently collecting data are dependent of patient clinical files with are not always complete. Nevertheless, data was collected prospectively and the double registration in paper and informatics support may avoid missing data. Also, the exact pathophysiological mechanisms of electrolytic changes were not assessed and comorbidities that could indirectly affect electrolyte balance were not explored.

This study provides teams taking care of PEG patients with a simple marker of poor outcome and reduced survival that may be looked at an easy and accessible tool that may contribute for signaling patients in whom PEG may be inadequate.

\section{CONCLUSION}

Changes in serum electrolytes in patients undergoing PEG were very common. More than half of the patients had at least one abnormality, at the time of the procedure. The most frequent was hyponatremia, which is associated with significantly shorter survival, probably reflecting severe systemic metabolic distress. Taking into account the results of the present study, the authors suggest that nutritional support teams routinely perform a complete evaluation of the main serum electrolytes before PEG placement and consider a careful monitoring in those who had hyponatremia, which may signal severe malnutrition induced metabolic imbalance and negative impact in the outcome.

\section{Authors' contributions}

Vieira J: research, data collection, survey execution, writing and translation of text. Nunes G: writing the text, statistical analysis. Santos CA and Fonseca J: review of the manuscript and study supervision.

Vieira J, Nunes G, Santos CA, Fonseca J. Eletrólitos séricos e prognóstico em doentes submetidos a gastrostomia endoscópica. Arq Gastroenterol. 2018;55(1):41-5.

RESUMO - Contexto - A gastrostomia endoscópica percutânea (PEG) é a via de eleição preferencial para a nutrição entérica de longa duração. A disfagia neurológica e as neoplasias cervico-faciais constituem as principais indicações para PEG por poderem conduzir a desnutrição energético-proteica e alterações hidroeletrolíticas, com potencial impacto negativo no equilíbrio metabólico. A síndrome de realimentação pode também estar associada a alterações hidroeletrolíticas graves em doentes alimentados por PEG e contribuir para um mau prognóstico. Objetivo - Avaliar as alterações das concentrações séricas dos principais eletrólitos e a eventual associação entre os valores séricos alterados e o prognóstico dos doentes gastrostomizados. Métodos - Estudo retrospetivo realizado em doentes seguidos na Consulta de Nutrição Artificial do Hospital Garcia de Orta, propostos e submetidos a PEG, de 2010 a 2016 e que faleceram sob nutrição por PEG. Consideraram-se os valores séricos dos iões em estudo avaliados imediatamente antes do procedimento endoscópico de gastrostomia, obtidos por consulta do processo clínico. A sobrevida, após a realização da PEG até à morte foi registrada em meses. Resultados - Avaliaram-se 101 doentes. A sobrevida média pós-gastrostomia foi 6,55 meses. Destes, 59 apresentaram alterações de alguns iões no momento da realização da PEG. O sódio estava alterado em 31 (30,6\%), magnésio em 20 (19,8\%), cloro em 19 (18,8\%), potássio em $14(13,8 \%)$, cálcio em $10(9,9 \%)$ e o fósforo em $9(8,9 \%)$. Quando comparada a sobrevida dos doentes com valores de sódio baixo $(<135 \mathrm{mmol} / \mathrm{L})$ com a dos doentes com valores normais/elevados, esta foi 2,76 meses vs 7,80 meses, respectivamente $(P=0,007)$. Conclusão - As alterações dos eletrólitos séricos nos doentes submetidos a PEG foram muito frequentes, com mais de metade dos doentes a apresentarem pelo menos uma alteração aquando da realização do procedimento. A alteração mais frequente foi a hiponatrémia, associando-se a pior prognóstico com sobrevida significativamente mais curta, refletindo provavelmente um grave compromisso metabólico sistêmico.

DESCRITORES - Nutrição enteral. Gastrostomia. Eletrólitos. Hiponatremia. 


\section{REFERENCES}

1. Loser C, Aschl G, Hebuterne X, Mathus-Vliegen EM, Muscaritoli M, Niv Y, et al. ESPEN guidelines on artificial enteral nutrition--percutaneous endoscopic gastrostomy (PEG). Clinical nutrition. 2005; 24:848-61.

2. Cecconi E, Di Piero V. Dysphagia--pathophysiology, diagnosis and treatment. Frontiers of neurology and neuroscience. 2012;30:86-9.

3. National Collaborating Centre for Acute Care. Nutrition support for adults: oral nutrition support, enteral tube feeding and parenteral nutrition. 2006

4. Raykher A, Russo L, Schattner M, Schwartz L, Scott B, Shike M. Enteral nutrition support of head or neck cancer patients. Nutrition in clinical practice: official publication of the American Society for Parenteral and Enteral Nutrition. 2007;22:68-73.

5. Fonseca J, Santos CA. Anatomia aplicada à clínica: antropometria na avaliação nutricional de 367 adultos submetidos a gastrostomia endoscópica. Acta Med Port. 2013;26:212-8.

6. Fonseca J, Santos CA, Brito J. Malnutrition and clinical outcome of 234 head or neck cancer patients who underwent percutaneous endoscopic gastrostomy. Nutr Cancer. 2016;68:589-97.

7. Bailey JL, Sands JM, Franch HA. Water, Electrolytes and Acid-Base Metabolism. In: Modern Nutrition in Health and Disease. $11^{\mathrm{a}}$ ed. Philadelphia: Lippincott Williams \& Wilkins; 2014.

8. Gallager ML. Intake: the nutrients and their metabolism. In: Krause's Food and the Nutrition Care Process. 13th ed. Missouri: Elsevier; 2012

9. Friedli N, Stanga Z, Sobotka L, Culkin A, Kondrup J, Laviano A, et al. Revisiting the refeeding syndrome: results of a systematic review. Nutrition. 2017;35:151-60.

10. Manghat P, Sodi R, Swaminathan R. Phosphate homeostasis and disorders. Annals of clinical biochemistry. 2014:51:631-56.

11. Palmer BF, Clegg DJ. Physiology and pathophysiology of potassium homeostasis. Advances in physiology education. 2016;40:480-90.

12. Blomberg J, Lagergren P, Martin L, Mattsson F, Lagergren J. Albumin and C-reactive protein levels predict short-term mortality after percutaneous endoscopic gastrostomy in a prospective cohort study. Gastrointest Endosc. 2011:73:29-36.

13. Clarkston WK, Smith OJ, Walden JM. Percutaneous endoscopic gastrostomy and early mortality. South Med J. 1990;83:1433-6.

14. Figueiredo FA, da Costa MC, Pelosi AD, Martins RN, Machado L, Francioni E. Predicting outcomes and complications of percutaneous endoscopic gastrostomy. Endoscopy. 2007;39:333-8.

15. Friedenberg F, Jensen G, Gujral N, Braitman LE, Levine GM. Serum albumin is predictive of 30-day survival after percutaneous endoscopic gastrostomy. JPEN. 1997;21:72-4.

16. Fonseca J, Santos CA, Brito J. Predicting survival of endoscopic gastrostomy candidates using the underlying disease, serum cholesterol, albumin and transferrin levels. Nutr Hosp. 2013;28:1280-5.

17. Muratori R, Lisotti A, Fusaroli P, Caponi A, Gibiino G, Eusebi LH, et al. Severe hypernatremia as a predictor of mortality after percutaneous endoscopic gastrostomy (PEG) placement. Dig Liver Dis. 2016.
18. Boustiere C, Veitch A, Vanbiervliet G, Bulois P, Deprez P, Laquiere A, et al. Endoscopy and antiplatelet agents. European Society of Gastrointestinal Endoscopy (ESGE) Guideline. Endoscopy. 2011;43:445-61

19. Dormann AJ, Wejda B, Kahl S, Huchzermeyer H, Ebert MP, Malfertheiner P. Long-term results with a new introducer method with gastropexy for percutaneous endoscopic gastrostomy. Am J Gastroenterol. 2006;101:1229-34

20. Fonseca J, Santos CA, Frois-Borges M, Meira T, Oliveira G, Santos JC. Ostomy metastasis after pull endoscopic gastrostomy: a unique favorable outcome. Nutr Hosp. 2015;31:1879-81.

21. Powell-Tuck J, Hennessy EMA. Comparison of mid upper arm circumference, body mass index and weight loss as indices of undernutrition in acutely hospitalized patients. Clin Nutr 2003;22:307-12.

22. Barosa R, Roque Ramos L, Santos CA, Pereira M, Fonseca J. Mid Upper arm circumference and Powell-Tuck and Hennessy's equation correlate with body mass índex and can be used sequentially in gastrostomy fed patients. Clin Nutr. 2017. Clin Nutr. pii: S0261-561430294-7.

23. Pereira M, Santos C, Fonseca J. Body Mass Index Estimation on Gastrostomy Patients Using the Mid Upper Arm Circunference. J Aging Res Clin Pract. 2012;1:252-55

24. American Academy of Family Physicians, American Dietetic Association, National Council on the aging. Nutrition Intervention Manual for Professionals Caring for Older Americans. Washington DC: Nutritional Screening Initiative: s.n., 1992.

25. Bankhead R, Boullata J, Brantley S, Corkins M, Guenter P, Krenitsky J, et al. Enteral nutrition practice recommendations. JPEN. 2009; 33:122-67.

26. Longcroft-Wheaton G, Marden P, Colleypriest B, Gavin D, Taylor G, Farrant M. Understanding why patients die after gastrostomy tube insertion: a retrospective analysis of mortality. JPEN. 2009; 33:375-9.

27. Hoorn EJ, Lindemans J, Zietse R. Development of severe hyponatraemia in hospitalized patients: treatment-related risk factors and inadequate management. Nephrology, dialysis, transplantation: official publication of the European Dialysis and Transplant Association - European Renal Association. 2006;21:70-6.

28. Gosch M, Joosten-Gstrein B, Heppner HJ, Lechleitner M. Hyponatremia in geriatric inhospital patients: effects on results of a comprehensive geriatric assessment. Gerontology. 2012;58:430-40.

29. Doshi SM, Shah P, Lei X, Lahoti A, Salahudeen AK. Hyponatremia in hospitalized cancer patients and its impact on clinical outcomes. Am J Kidney Dis. 2012;59:222-8

30. Schrier RW, Sharma S, Shchekochikhin D. Hyponatraemia: more than just a marker of disease severity? Nephrology. 2013;9:37-50.

31. Owen J, Campbell D. A comparison of plasma electrolyte and urea values in healthy persons and in hospital patients. Clinica Chimica Acta. 1968;22:611-18.

32. Buffington MA, Abreo K. Hyponatremia: A Review. Journal of intensive care medicine. 2016;31:223-36. 